\title{
COMBINATIVENESS OF FRAME COMPOSITION IN THE CURRENT SCREEN SPACE FORMATIONS
}

Summary: The article examines the variability of non-standard frame composition, the displacement and interaction of visual objects, everything that is characteristic and specific to the structure of the screen space. The author focuses attention on the location of objects within the frame, which is experiencing a new actualisation, expressed, only at first glance, in an incorrectly built on-screen construct, when the composition of the frame implies, in some cases, the construction of an image with a change in its essential components. Artist I.Repin's artworks, on which the faces of the portrayed - R.Levitsky (1878) and P.Samoilov (1915), are depicted closer to the edge of the frame, are presented as illustrative material in this work. Attention is focused on similar features of the embodiment of characters' images in films ( $A r$ rhythmia, directed by B.Khlebnikov, 2017, Russia; The White Crow, directed by R.Fiennes, 2019, UK, France, Serbia), and in the programs of national television. Thus, the phenomenon of non-standard screen composition and the reasons for the increased use of this approach by camera operators when shaping a frame in modern media were considered using examples of paintings, cinematographic films, television materials. As a methodological basis, both theoretical and em-

In visualising the reality surrounding the recipient on the screen, the object of filming is es sential as an artefact. It is a specific object or a hero of a screen message, recorded in such a way as to convey their inner world, to create "a certain amount of suggestion" 1 that "does not reflect 1. Mankovskaya N.B. "Ice-bound Swan. Stefan Mallarmé's Aes-
thetic Views" // Hudojestvennaya kultura. 2020. No.1. P.7. pirical, general scientific and special methods wer used, which made it possible to clarify the properties of the compositional structure of the screen space as a diverse expressive form presenting audiovisual content to the viewer. The research was based on the Photocomposition theoretical course by L.Dyko and A.Golovni, as well as the scientific positions of L.Kuleshov, a director and theorist of cinema. At the same time, the content of the work was primarily determined by the experience of professional activity and the practical participation of the author in the creation of various screen products, including the ones based on which the analysis and theoretical substantiation of the practical necessity of the methods, actively used today in the creation of various screen compositions during the filming process and post-production, were made. The publication will attract the attention of specialists and be of in terest to a wide range of readers and viewers since the problem of the combinatorial composition of the frame remains a significant issue in the construction of screen space in the field of television, cinema and the Internet resources.

Keywords: angle, cinema, composition, frame screen space, television

things but permeates them, shows the inexpressible, conveys not the image of the object $\langle\ldots\rangle$ but its inexpressible essence in sensations, feelings" 2 as Doctor of Philosophy N.Mankovskaya emphasises.

2. Ibid. P.8.
In this context, S.Mallarmé believed that it is necessary "to picture not the thing itself but the im pression it makes" 3 . We need a route for developing compositional dialogue in a "strict pattern - the sequence of movement of the gaze from one semantic element to another. In this regard, it is correct to consider not individual elements as a composite but the ones taken in a complex manner, togeth er with their interconnections and relations" ${ }^{4}$, says Professor A.Sveshnikov.

As it is known, visualisation of objective reality is associated with compositional filling of the frame and close attention to the background as a clarifying spatial pattern of the shooting object location. The object's location relative to the background surface plays a significant role. When other objects of the frame composition partially overlap the background, the effect of truncated reality ${ }^{5}$ occurs since part of the screen space disappears from the view.

Placement of the image in screen space is an essential aspect of the combinatorial composition of the frame. The angle of shooting the object, its dynamics in the mise-en-scene, the direction of gaze, $i$ the object is an actor in the episode, have to be considered. At the same time, the laws of constructing the composition of the frame are observed. Together with L.Dyko and A.Smut, the well-known Soviet cameramen, the authors of the textbook on photocomposition, we understand it as "a whole system, the entire pictorial structure of the shot $\langle\ldots\rangle$ in order to reveal the ideological and thematic content,$\langle\ldots\rangle$ to achieve clarity and expressiveness of the artistic form" 6 .

As we know, in the classical construction of the composition, the rule of thirds, based on the visual division of the frame into nine equal parts using two vertical and two horizontal lines, is taken into account. "The main parts of the composition, bearing an important semantic load, should be located . Mallarmé S. Works in Poetry and Prose. Collection Moscow: Raduga, 1995. P.382.

Sveshnikov A.V. "Current Problems of Artistic Image Composition" // Vestnik VGIK. 2019. Vol.11. No.2. P.93.

The essence of the phenomenon of truncated reality, its properties and features of manifestation were examined in detal in the article "The Phenomenon of Truncated Reality as a ViEvent in the Space of a Television Frame" // Actual problems of the screen and interactive media: Collection of materials of the scientific-practical conference. Moscow, October 29-30, 2018 / Compiler and scientific editor - Doctor of Art History. Professor N.Krivulya. Moscow: Publishing house of Moscow
University, 2019. Pp.161-166. Dyko L.P., Golo.
vo, 1962. P.28.

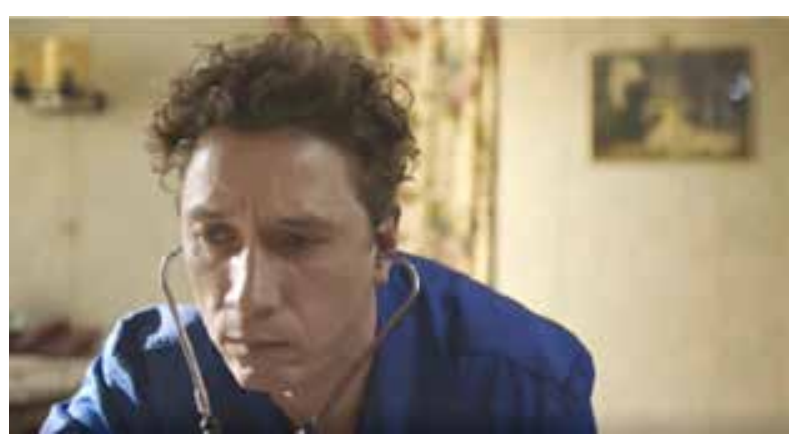

Figure 1 - Screenshot of a frame from the film Arrhythmia,
directed by B.Khlebnikov, 2017. Russia.

either along these lines or at their intersection - at points of power. It is this arrangement that allows the viewer's attention to be focused on the important details of the picture with a high concentration of energy" . At the same time, L.Dyko considers "the movement developing in the frame, its direction" to be the motive for the balanced composition "and then the unfilled part of the frame acquires meaning and significance ${ }^{\prime \prime}$.

The creative process of making a composition involves several changes in the classical placement of the hero's image. Thus, in the picturesque portraits of R.Levitsky (1878) and P.Samoilov (1915) by I.Repin, the faces are depicted closer to the moulding in the direction of their gaze. Similar features of the embodiment of characters' images are noted both on television and in cinema. Let us turn to the motion picture Arrhythmia (directed by B.Khlebnikov 2017, Russia). The video sequence of the film emphasises the inner state of one of the heroes, whose image is near the border of the frame (Fig. 1). The cameraman's way of creating this composition can be interpreted as the desire of the ambulance doctor Oleg Mironov, to come to the rescue faster $\mathrm{Hi}$ image, almost leaving the frame in the direction of the patient, shows it.

In this context, we quote L.Kuleshov's words: "Extra things and extra space in the frame must be removed"9. Lev Kuleshov's statement still sounds like n axiom almost a century later. However, the character of A.Yatsenko, located as close as possible to one of the borders of the frame, frees up a signifi7. "Frame Composition and Rule of Thirds" // Dec 2016, 6. Available at: https://bekarstudio.ru/kak-horosho-fotografirovat-ilisnimat-video/article_post/kompozitsiya-kadra-i-pravilo-tretey (accessed: 26.09.2020),

Dyko L.P. "Basics of Composition in Photography" // Available at: http://www.photoline.ru/books/diko-osnovikompozicii.pd Kuleshov LV The Art of Cin chat, 1929. P.79. 

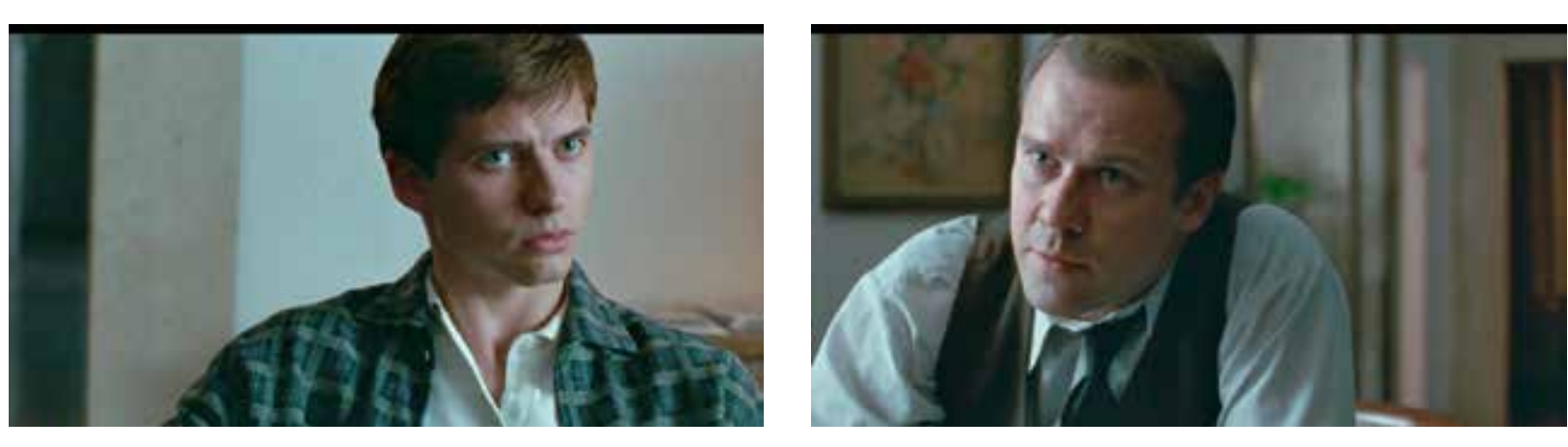

Figure 2 - Screenshots of frames from the film The White Crow, directed by R.Fiennes, 2019, UK, France, Serbia

cant amount of screen space behind since "the proportions of the screen do not always allow to show the desired action so that it would fit without unnecessary surroundings on the screen" 10 .

The combinatorial nature of the composition in replenishing the "free" space when creating expressive screen constructs is dictated by the actual creative decisions of the authors of the materials. A.Sveshnikov points out that "formally 'correct' composition, divorced from meaning, does not exist. What is right for one artistic task may be absolutely unacceptable for another ${ }^{\prime \prime 1}$. It is in line both for a specific position of the object in the frame, and for a non-classical construction of the entire onscreen composition. In this context, we will consider non-standard compositional solutions when embodying a creative idea in a visual work.

The first option will be illustrated with a fragment 2019, UK, France, Serbia). We see actors positioned separately in adjacent frames (Fig. 2). At the same time, everyone's gaze is directed to their counterpart in the episode since the 180-degree shooting technique in the mise-en-scene fixes the location of the cameras on one side of the conditional line passing through the points of placement of the interlocutors. Moreover, in addition to bringing the actors closer together at the level of editing, there 10. Ibid.

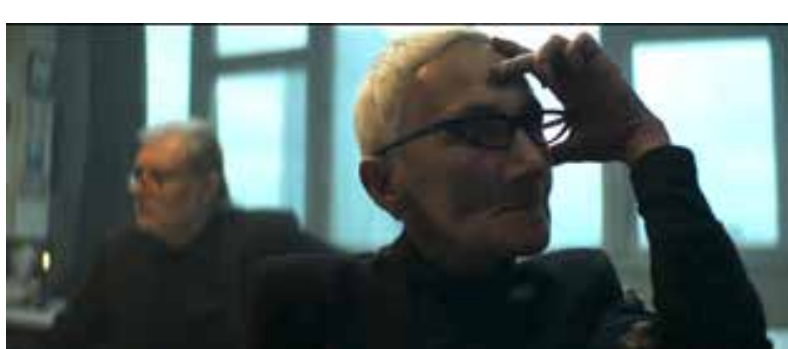

Figure 4 - Screenshots of frames from the TV series Psycho Spleen with one change: the mother of the character
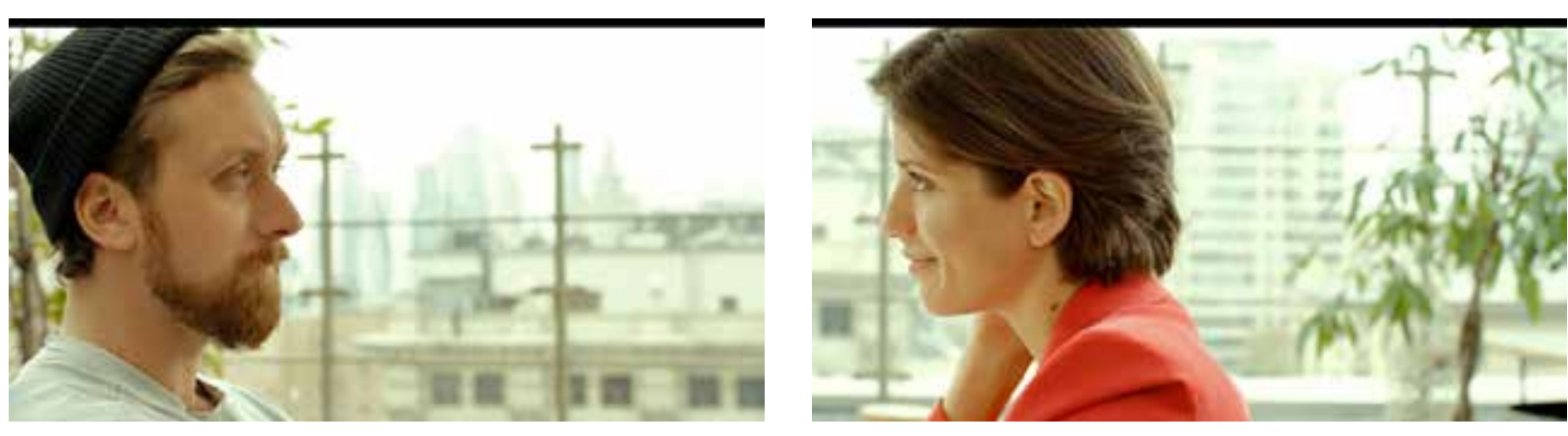

Figure 3 - Screenshots of frames from the film Russian Spleen, directed by A.Kamynin, 2019, Russia.

front of the hero of a piece of television material to the edge of the frame window, in turn, indicates that the properties of the classical composition are not observed. However, this structure should be considered more broadly, in conjunction of this frame with the next one (Fig. 5, on the right), in which the subject enters the building. Its given position in screen space harmoniously joins since the object is located in the same part of the composition in both frames.

In the second variant, the compositional completeness of the frame is achieved with the help of additional images of objects on the background surface, for instance, a monitor-decoration, or filling the screen space with various visual objects in the form of a light frame made of visually tangible rays, which are like a continuation of the hero's image on the screen (Fig. 6). The combination of the projection of the actor's figure with the visible backlight stream on the screen forms a single plastic construct balancing the frame composition. Moreover, in the television show The Voice (Channel One), a halfway display of the performer's face was implemented - let us mark this variant of the non-standard frame composition as the third one. Despite the shifted boundaries of the frame compared with the girl's portrait, the conceptual idea of the technique can be justified by the stylistic design of the piece of music on the screen.
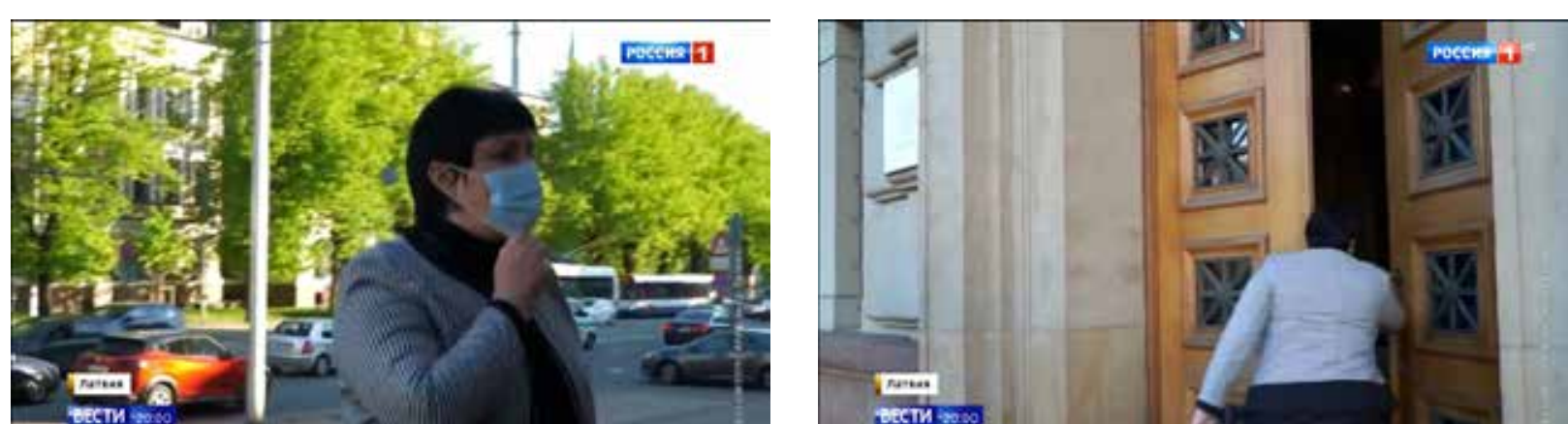

Figure 5 - Screenshots of frames from the program Vesti at 20:00 (TV broadcast: 26.05.2021) // Russia 1.

Fourthly, non-standard solutions in the construc tion of the frame composition are also explained by the unplanned actions of the subject of filming. When preparing a TV report, the adoption of one or another operator's approaches may occur due to a short-term change in the hero's position in the mise-en-scene. When they are turned in the opposite direction while communicating with two or more interlocutors located on different sides of the lens axis, the gaze will again "rest" on the edge of the frame (Fig. 7).

At this point, it is impractical to correct the com position due to the forced sharp horizontal panning in the opposite direction when the speaker returns to their original position. In this regard, a compositional collision will be observed on the screen for some time, which is less sensitive for visual percep tion than a quick movement of the picture. In this situation, a short "wrong" composition of the frame saves the overall visual stability of the construct of the screen space of television material.

The fifth variant of the on-screen construction is because the central element of the composition is shifted not along the horizon but to the bottom of the frame. Such a composition opens up a deep perspective of the mise-en-scene in visual narration (Fig. 8). A professional discussion about such on-screen compositions occurred even earlier when the Soviet camera school was actively deof the film The White Crow (directed by R.Fiennes,

1. Sveshnikov A.V. "Current Problems of Artistic Image Compo- is a kind of visual attraction in the frame due to the displacement of the characters in the composition to the minimum distance of screen interaction, which increases the tension of the dialogue and the genral atmosphere in the mise-en-scene.

Compositions, in which the in-screen displacement of the characters of the film is mastered, were considered acceptable in the graduation works of VGIK students in the middle of the last century (Hey Someonel, a shot film direted by A S minov, BYashin, 1963, Mosfilm) as well as during our days (Double Duty in a Love Stupor, directed by A.Unaev, A.Lavrentyev, V.Runov, 2021, VGIK). This fact indicates the academic nature of this creative technique, which is used while creating the appropriate frames. Similar solutions are used in the creation of television advertising material.

The following screenshots of frames from the film Russian Spleen (directed by A.Kamynin, 2019, Russia) indicate that in them, only one of the interacting actors is located in the direction of their gaze closer to the edge of the screen (Fig. 3). Seeing this scene on the screen, the viewer might thin that the heroine of the plot seems to be drawn to the young man, who, in turn, does not reciprocate. Next, let us consider a scene from the Psycho TV series (directed by F.Bondarchuk, 2020, Russia), in which, as we can later understand, family members do not communicate well. The director of photography used a similar technique as in the film Russian played by K.Bogomolov turns away from her interlocutors and, again, is located in the frame adjoining the edge of the screen, which the viewer can visually regard as an additional accent at her distance from her son (Fig. 4).

In the next frame from the Vesti at 20:00 program (Russia One TV channel), the panning of the object falls short behind its movement in the episode (Fig. 5, on the left). Insufficient distance in 


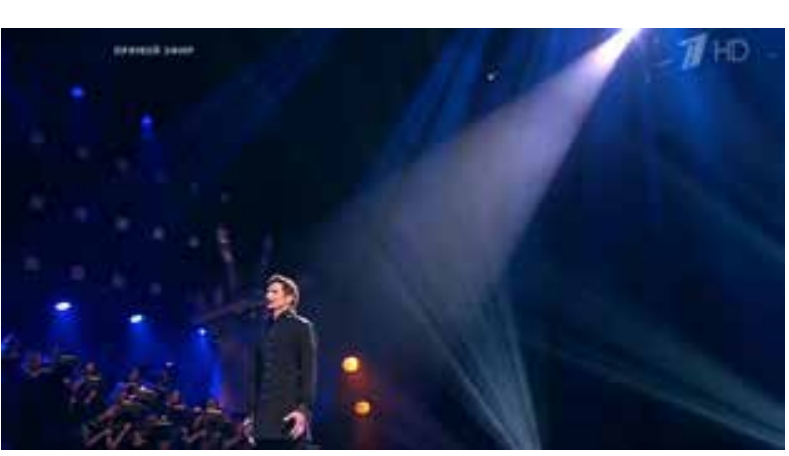

Figure 6 - Screenshot from the music show The Voice

Channel One.
Che

veloping its methods and techniques. Here is an excerpt from L.Kuleshov's book The Art of Cinema published in 1929:

"There is, for example, a theory that when shooting a landscape in general, it is necessary to show the horizon line so that it separates one third (the top) of the frame. Aren't there enough examples of exceptionally expressive shots, filmed without a 'horizontal third'? Comrade Kuznetsov $\langle\ldots\rangle$, don't you remember how we argued about the horizon line at the beginning of our work? And didn't you later choose the frames with the horizon occupying one-tenth of the frame below and the parts with no horizon at all in By the Law? Now you are one of the best Soviet cameramen. Isn't it easier to work after you and I have forgotten a good old tradition, which is worthless?!" 12 .

To develop the theme, let us turn to the construction of the composition, affecting, in addition to two dimensions, the third coordinate in the direction from the foreground deep into the miseen-scene. This vector contains the problem of the different angles of displaying two graphic planes with the object of filming and the background behind it, shown on the screen-decoration (Fig. 9). The complex structure of the frame is built using two planes of the screen space, on which objects are displayed, fixed from different angles of filming. Thus, the overall screen picture shows both the dynamics of the composition and the visual tightening of the frame, which, by the way, solves the problem of organizing the reporter's live broadcast from the scene using multi-portrait compositions.

The television split-screen resembles the juxtaposition of adjacent frames in a cut, with one fundamental difference - vertical portrait mono compositions 12. Kuleshov L.V. The Art of Cinema. Leningrad: Teater-Kino-Pechat, 1929. Pp.81-82.

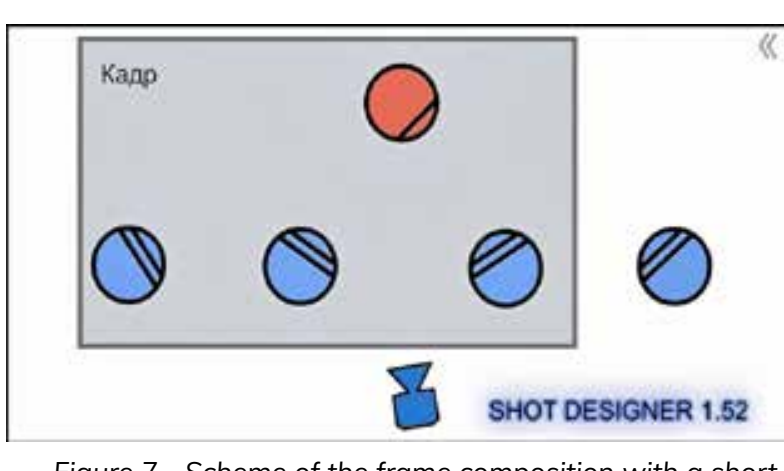

Figure 7 - Scheme of the frame composition with a shortTV camera on the opposite side.

are present on the screen at the same time. Through the split-screen windows presented to the viewe the emotions of each participant in the teleconference are instantly conveyed Moreover, the way to the adjustment of individual images both in scale and in brightness and colour settings becomes available. From an artistic point of view, this phenom enon is very significant. The television audience is in constant eye contact with the news anchors and the reporter.

At the same time, let us note that vertically oriented individual images that do not coincide in size with the display surface of the screen harmoniously fill its field in their certain number. The portrait composition has confidently fixed on the screens of mobile electronic devices, pragmatically built when shooting video content, taking into account the anatomically convenient location of the smartphone in the user's hand. Under these conditions, the composition of the frame becomes photographically denser since the proportions of the object in the horizontal plan correlate with the given screen format.

$$
\text { *** }
$$

The variability of the on-screen display of objects, which differs from the classical canons, actualises the question of finding and applying origina creative solutions for the director of photography. However, the implementation of a particular visual construct can be continued in post-production. At the same time, a justified approach is required in the use of non-standard compositions, the redundancy of which should not be misused since, due to the small amount in the visual work they attract the viewer's attention and help to convey a deeper meaning in the pictorial structure of the frame.

The theoretical comprehension of the transformations of the screen space is certainly not absolutely

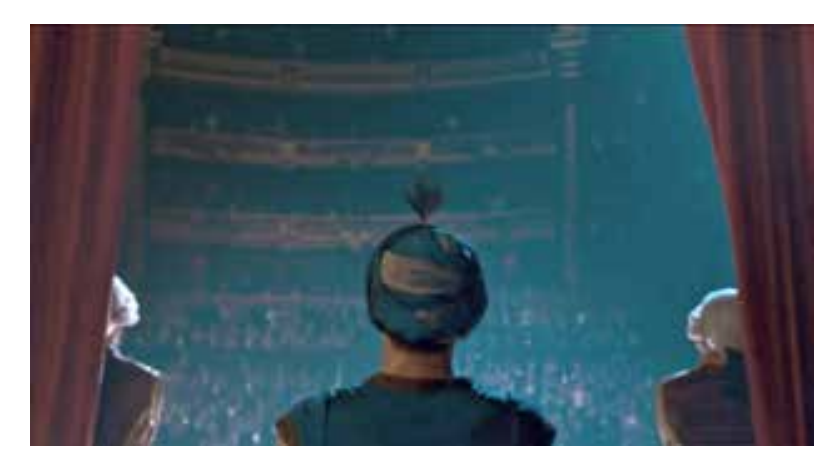

Figure 8 - Screenshot of a frame from the film The White

finite. The potential of combinatorics of composition needs further refinement and expansion, a description of new methods for managing the structure of the frame. In light of the constant improvement of modern approaches to the creation of screen compositions as well as to the technical base with

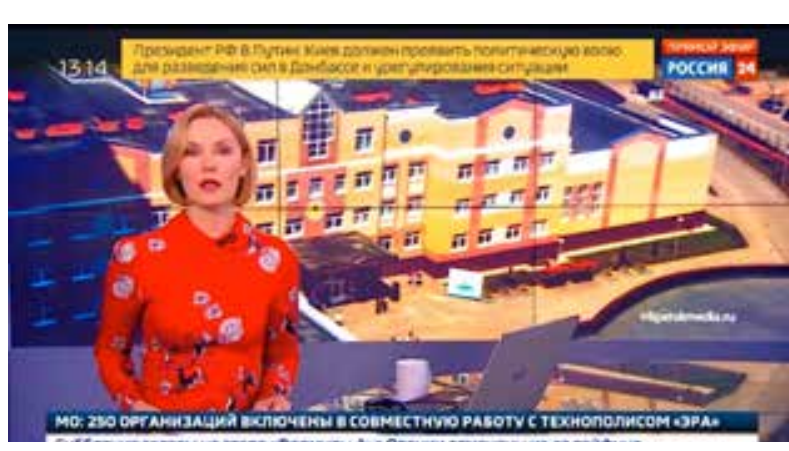

Figure 9 - Screenshot of a frame from the content of the TV Figure 9 - Screensh
channel Russia 24.

the help of which a copy of the reality surround ing the recipient is reproduced, the phenomenon of "non-standard" composition in the actual constructions of the screen space both in the field of television and cinema and visual arts, in general, requires further studying.

\section{REFERENCES}

1. Dyko, L.P. Osnovy Kompozicii v Fotografii [Basics of Composition in Photography]. Available at: http:// www photoline ru/books/diko-osnovikompoziciipdf (accessed: 25.11.2020). (In Rus.)

2. Dyko, L.P., Golovnya A.D. Fotokompoziciya [Photocomposition]. Moscow: Iskusstvo, 1962. P.261. (In Rus)

3. Kompoziciya Kadra i Pravilo Tretej. 2016. Available at: https://bekarstudio ru/kak-horosho-fotografirovat-ilisnimat-video/article post/kompozitsiya-kadra-i-pravilo-tretey (accessed: 26.09.2020). (In Rus.)

Kuleshov, LV1929. Iskusstvo Kino [The Art of Film]

Leningrad: Tea-Kino-Pechat', p.155. (In Rus.)
5. Mallarme, S. 1995. Sochineniya v Stikhakh i Proze Sbornik [Works in poetry and prose. Collection]. Moscow: Raduga, p. 568. (In Rus.)

6. Man'kovskaya, N.B. 2020. "Lebed', Zakovanny L'dom. Ehsteticheskie Vozzreniya Stefana Mallarme" 7. Sveshnikov, A.V. 2019. "Aktual'nye Problemy Kom pozicii Khudozhestvennogo Izobrazheniya" ["C Kom problems of artistic image composition"] Vestnik VGIK, vol. 11, no. 2, pp.87-99. (In Rus.) ["Ice-bound swan. Stefan Mallarmé's aesthetic views", Khudozhestvennaya kul'tura, no1, pp.1-28. (In Rus). 
Владимир Васильевич Шабалин кандидат e-mail:v-shabalin@mail.ru

Россия, Москва

ORCID ID: 0000-0001-5752-2983

DOI: 10.36340/2071-6818-2021-17-3-90-100

\section{КОМБИНАТОРНОСТЬ КОМПОЗИЦИИ КАДРА \\ В АКТУАЛЬНЫХ ПОСТРОЕНИЯХ ЭКРАННОГО ПРОСТРАНСТВА}

Аннотация: В статье рассматривается вариативность нестандартной композиции кадра, смещение и взаимодействие визуальных объектов которой имманентно сопутствует структуре экранного пространства визуального произведения. Автор фокусирует внимание на пережи вающем новую актуализацию расположении объектов в границах кадра, только на первый взгляд выражаемом в некорректно выстроенном экранном конструкте, когда композиция кадра предполагает в некоторых случаях построение изображения с изменением ее базовых составляющих. В качестве иллюстративного материала в настоящей работе приводятся произведения художника И.Е. Репина, на которых лица портретируемых Р.С. Левицкого (1878) и П.В. Самойлова (1915) изображены ближе к краю рамы. Заостряется внимание на подобных особенностях воплощения образов персонажей и в кинофильмах («Аритмия», реж. Б. Хлебников, 2017, Россия; «Нуреев. Белый ворон»/The White Crow/ реж. Р. Файнс, 2019, Великобритания, Франция, (ербия), и в программах отечественного телевидения. Таким образом, на примерах произведений живописи, кинематографических картин, телевизионных материалов рассматривался феномен нестандартной экранной композиции и причины участившегося применения данного подхода операторами при формировании кадра

В процессе визуализации на экране окружающей реципиента действительности объект съёмки важен как артефакт, представляющий собой в современных медиа. В качестве методологической основы применялись как теоретические, так и эмпирические, общенаучные и специальные методы, которые позволили уточнить свойства композиционной структуры экранного пространства как многообразной выразительной формы представляющей аудиовизуальный контент зрителю. Исследование опиралось на теоретический курс «Фотокомпозиция» Л.П. Дыко и А.Д. Головни, а также научные положения режиссёра теоретика кино Л. Кулешова. Вместе с тем со держание работы во многом определил опы профессиональной деятельности и практическое участие автора в создании различных экранных продуктов, в том числе на основании которых проведён анализ и теоретическое обоснование практической необходимости методов, активно применяемых сегодня при создании многообразных экранных композиций как во врем съёмочного процесса, так и на постпродакшене. Публикация привлечёт внимание специалистов а также заинтересует широкий круг читателей и телезрителей, так как проблематика комби наторности композиции кадра остаётся весьвопросом в построении экранного пространства в области телевидения, кинема тографа и интернет-ресурсов.

Ключевые слова: кинематограф, композиция, кадр, ракурс, телевидение, экранное пространство.

конкретный предмет или героя экранного сообщения, фиксируемого таким образом, чтобы передать его внутренний мир, создать «некоторую толику суггестии» ${ }^{1}$, которая «не отражает вещи, а проникает в них, говорит о невыразимом, передает не образ предмета $<\ldots .>$, но его невыразимую суть в ощущениях, чувствахм2, - пОдчеркивает доктор фил

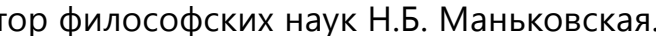

В данном контексте С. Малларме полагал, что необходимо «рисовать не саму вещь, но впечатление, которое она производит» ${ }^{3}$. Нужен маршрут развития композиционного диалога в «строгой закономерности - последовательности передвижения взгляда от одного смыслового элемента к другому. В связи с этим правильнее считать композитом не отдельные элементы, а взятые комплексно, вместе с их взаимосвязями и отношениями» ${ }^{4}$ - считает профессор А.В. Свешников.

Как известно, визуализация предметной реальности сопряжена с композиционным заполнением кадра, в том числе с пристальным вниманием к фону как уточняющему пространственному паттерну локации объекта съёмки. Расположение объекта относительно фоновой поверхности играет знаковую роль. При частичном перекрытии фона другими объектами композиции кадра воз никает эффект усечённой реальности ${ }^{5}$, поскольку часть экранного пространства уходит из поля зрения.

Размещение образа в экранном пространстве - существенный аспект комбинаторности композиции кадра с учётом ракурса съёмки объекта его динамики в мизансцене, направления взгляда, если объект является действующим лицом в эпизоде. При этом соблюдаются законы построения композиции кадра, которую вслед за известными советскими кинооператорами, авторами учебного пособия по фотокомпозиции Л.П. Дыко и А.Д. Головни, понимаем как «всю систему, весь изобразительный строй снимка <...>

1. Маньковская Н.Б. Лебедь, закованный льдом. Эстетические воззрения Стефана Малларме // Художественная культуpa. 2020. № 1. C. 7.

. Малларме С. Соиинения в стихах и прозе: Сборник. М. Ра дуга, 1995. С. 382.

Свешников А.В. Актуальные проблемы композиции художественного изображения // Вестник ВГИК. 2019. Т. 11 № 2. C. 93 .

5. Сущность феномена усечённой реальности, его свойства В особенности проявления мы подробно рассматривали ный троп экранной интерпретации образа события в пространстве телевизионного кадра» // Актуальные проблемы экранных и интерактивных медиа: Сборник материалов баучно-практической конференции. Москва, 29-30 октяфря 2018 Н Сост. и науч. ред. д-р искусствоведения, проверситета, 2019. С. 161-166. в целях раскрытия идейно-тематического содер жания, <..> достижения чёткости и выразительности художественной формы» ${ }^{6}$

В классическом построении композиции, как мы знаем, учитывается «правило трете́й», основанное на зрительном разделении кадра на девять равных частей с помощью двух вертикальных и двух горизонтальных линий. «Основные части композиции, несущие важную смысловую нагрузку, должны располагаться либо вдоль этих линий, либо на их пересечении - в точках силь. Именно такое расположение позволяет акцентировать внимание зрителя на первостепенных, обладающих большой концентрацией энергии деталях снимка» 7 . Вместе с тем Л.П. Дыко считает иотивом исполнения равновесной композици «развивающееся в кадре движение, его направление, и тогда незаполненная часть кадра приобретает свой смысл и значение»8.

Творческий процесс построения композиции предполагает ряд изменений в классическом размещении образа героя. Так в живописных портретах Р.С. Левицкого (1878) и П.В. Самойлова (1915) кисти И.Е. Репина лица портретируемых изобра жены ближе к багету по направлению их взгля да. Подобные особенности воплощения образов персонажей отмечаются и на телевидении, и кинематографе. Обратимся к кинокартине «Арит мия» (реж. Б. Хлебников, 2017, Россия). Видеоряд фильма подчёркивает внутреннее состояние одного из героев, образ которого «утыкается» в рамку кадра (рис. 1). Операторское решение по выстраиванию данной композиции может трактоваться как стремление врача скорой помощи Олега Миронова быстрее прийти на помощь, что и показывает его образ, почти выходящий из кадра в сторону пациента.

В этом контексте приведём слова Л. Кулешова: «Лишние вещи и лишнее пространство в кадре должны быть убраны» ${ }^{9}$. Высказывание Льва Владимировича спустя почти столетие по-прежнему звучит как аксиома. Но персонаж А. Яценко, Дыко Л.П., Головня А.Д. Фотокомпозиция. М.: Искусство, 1962. C. 28.

Композиция кадра и правило третей ГЭлектронный реru/kak-horosho-fotografirovat-ili-snimat-video/article_post/ kompozitsiya-kadra-i-pravilo-tretey (дата обращения: 26.09.2020).

Дыко Л.П. Основы композиции в фотографии [Электронный ресурс]. Режим доступа: http://www.photoline.ru/books/diko-

9. Кулешов Л.В. Искусство кино. Л.: Театр-Кино-Печать, 1929 
максимально приближенный к одной из сторон кадра, высвобождает значительный объём экранного пространства за ним, потому что «пропорции экрана не всегда позволяют показать нужное действие так, чтобы оно поместилось на экране без излишнего окружения» ${ }^{10}$.

Комбинаторность композиции в восполнении “Свободного» пространства при создании выра“ительных экранных конструктов продиктована актуальными творческими решениями авторов материалов. А.В. Свешников указывает, что «формально "правильной" композиции, то есть оторванной от смысла, не существует. Что правильно для одной художественной задачи, может быть абсолютно недопустимо для другой» ${ }^{11}$. Это соответствует как для определённого расположения объекта в кадре, так и для неклассического построения всей экранной композиции. В этом контексте рассмотрим нестандартные компози ционные решения при воплощении творческого замысла в визуальном произведении.

Первый вариант проиллюстрируем фрагментом фильма «Нуреев. Белый ворон» (The White Crow, реж. Р. Файнс, 2019, Великобритания, Франция, Сербия). Мы видим актёров, расположенных по отдельности в смежных кадрах (рис. 2). При этом взгляд каждого обращён на своего визави по эпизоду, так как съёмочный приём «восьмёрка» в мизансцене закрепляет расположение камер с одной стороны от условной линии, проходящей через точки размещения собеседников. Более того, помимо сближения актёров на уровне монтажной склейки, происходит своего рода их визуальное притяжение в кадре за счёт смещения персонажей в композиции к минимальной дистанции экранного взаимодействия, что усиливает напряжённость диалога и общей обстановки в мизансцене.

Композиции, в которых осваивается внутриэкранное смещение образов героев кинофильма считаются приемлемыми в выпускных работах студентов ВГИКа как середины прошлого века («Эй, кто-нибудь!», короткометражный, реж. А. Смирнов, Б. Яшин, 1963, Мосфильм), так и в наши дни («Двойное дежурство в любовном угаре», реж. А. Унаев, А. Лаврентьев, В. Рунов, 2021, ВГИК), что указывает на академичность данного творче-

10. Там же.
11. Свешников А.В. Актуал

художественного изобральнения // Вестник ВГИК 2019.Ти

художестве
№2. С. 92. ского приёма, имеющего место при выстраивании соответствующих кадров. Подобные решени применяются и при создании телевизионного рекламного материала.

Следующие скриншоты кадров из кинокартины «Хандра» (реж. А. Камынин, 2019, Россия) показательны тем, что в них только один из взаимодействующих актёров расположен по направлению его взгляда ближе к краю экрана (рис. 3). Героиня сюжета как бы тянется к молодому человеку, который в свою очередь не отвечает ей взаимностью, увидев эту сцену на экране, може решить зритель.

Далее рассмотрим сцену из сериала «Псих (реж. Ф. Бондарчук, 2020, Россия), в которой у членов семьи, как мы позднее можем понять, общение не складывается. Оператором-постановщиком применяется аналогичный приём, что и в кинофильме «Хандра» с одним изменением: мама персонажа К. Богомолова отворачивается от своих собеседников, и, опять же, располагается в кадре, примыкая лицом к краю экрана что может визуально расцениваться зрителем как дополнительный акцент на её отдалении от сына (рис. 4).

В следующем кадре из программы «Вести в 20:00» (телеканал «Россия 1») панорамирование за объектом отстаёт от его движения в эпизоде (рис. 5, слева). Недостаточное расстояние перед героем фрагмента телевизионного материала до края кадрового окна в свою очередь, гОворит о несоблюдении свойств классической композиции. Но данное построение нужно рассматри вать шире, в связке этого кадра с последующим (рис. 5, справа), в котором объект съёмки входи в здание. Данное его расположение в экранном пространстве гармонично состыковывается, так как в обоих кадрах объект расположен в одной и той же части композиции.

Во втором варианте достижение композиционной завершённости кадра происходит с по мощью дополнительных образов объектов на фоновой поверхности, например, монитора-декорации или заполнения экранного простран ства различными визуальными объектами в виде светового каркаса из зрительно осязаемых лучей, являющихся словно продолжением образа героя на экране (рис. 6). Соединение проекции фигуры артиста с видимым потоком контрового света на экране образует единый пластический конструкт, уравновешивающий композицию ка- дра. Более того, в том же телевизионном шоу «Голос» (Первый канал) было реализовано половинчатое отображение лица исполнительницы - отметим этот вариант нестандартной компоновки кадра как третий. Несмотря на сдвинутые границы кадра по отношению к портрету девушки, концептуальный замысел приёма можно обосновать стилистическим оформлением музыкального произведения на экране.

В-четвертых, нестандартные решения в построении композиции кадра объясняются и незапланированными действиями объекта съёмки. При подготовке телерепортажа принятие того или иного операторского решения «с колёс» может жения героя события в мизансцене. При его повороте в противоположную сторону при общении с двумя или более собеседниками, располагае мыми с разных сторон от оси объектива, взгляд будет вновь «упираться» в край кадра (рис. 7).

В этот момент корректировать композицию нецелесообразно по причине вынужденного резкого горизонтального панорамирования в обратном направлении, когда спикер вернётся в исходное положение. В связи с этим на экране некоторое время будет наблюдаться композиционная коллизия, что менее чувствительно для зрительного восприятия, нежели «дерганье картинки». В этой ситуации непродолжительная «не правильная» композиция кадра спасает общую визуальную устойчивость конструкта экранного пространства телевизионного материала.

Пятый вариант экранного построения обу словлен тем, что главный элемент композиции смещается не по линии горизонта, а в низ кадра. Такая композиция открывает в визуальном повествовании глубинную перспективу мизансцены (рис. 8). О подобных экранных композициях шла профессиональная дискуссия и ранее, когда советская операторская школа активно нарабатывала свои методы и приёмы. Приведём отрывок из книги Л. Кулешова «Искусство кино», изданной в 1929 году:

«Существует, например, теория, что при съёмке пейзажа общим планом необходимо показать линию горизонта, да ещё так, чтобы она отделяла одну треть (верхнюю) кадра. Неужели недостаточно примеров исключительно выразительных кадров, заснятых не с "горизонтальной третью?" Товарищ Кузнецов $\langle\ldots .$. , разве не помните, ка в начале нашей работы мы спорили о линии го- ризонта? И разве позднее вы не сами выбрали кадры в "По закону" с горизонтом, занимающим одну десятую кадра внизу, и куски совершенно без горизонта? Теперь вы один из лучших советских операторов. Разве не легче стало работать когда мы с вами похоронили добрую старую традицию, которой грош цена?!»12.

В развитие темы обратимся к выстраиванию композиции, затрагивающему помимо двух измерений и третью координату в направлении от переднего плана вглубь мизансцены. В этом векторе кроется проблематика разноракурсности отображения двух изобразительных плоскостей с объектом съёмки и находящимся за ним фоном, демонстрируемым на экране-декорации (рис. 9). Сложносоставная структура кадра выстраивается с помощью двух плоскостей экранного пространства, на которых отображаются объекты, зафиксированные с разных ракурсов съёмки. Таким образом, на общей экранной картине просматривается и динамика композиции, и визуальное уплотнение кадра, которое, кстати, ре шает задачу организации «прямого» включени репортёра в эфир с места события с применени ем мультипортретных композиций.

Телевизионный полиэкран напоминает сопоставление смежных кадров в монтажной склейке с одним принципиальным отличием - вертикальные портретные монокомпозиции присутствуют на экране одновременно. Посредством представляемых зрителю окон полиэкрана одномоментно доносятся эмоции каждого участника телемоста, более того, открывается путь к независимой корректировке отдельных изображений как по масштабу, так и по яркостно-колористическим настройкам. С художественной точки зрения это явление весьма значимо, как и тот факт, что телеаудитория при этом находится в постоянном зрительном контакте с ведущими новостного выпуска и корреспондентом.

Вместе с тем отметим, вертикально ориентированные отдельные изображения, не совпадающие по габаритам с отображающей поверхностью экрана, в некотором их количестве гармонич но заполняют его поле. Портретная композиция уверенно закрепилась и на экранах мобильных электронных устройств, прагматично выстраи ваемая при съёмке видеоконтента с учётом анатомически удобного расположения смартфона в

12. Кулешов Л.В. Искусство кино. Л.: Театр-Кино-Печать, 1929 
руке пользователя. В данных условиях композиция кадра становится фотографически плотнее, так как пропорции объекта при поясном плане коррелируют с данным форматом экрана.

$$
* * *
$$

Вариативность экранного отображения объектов, отличающегося от классических канонов, актуализирует перед оператором-постановщиком вопрос поиска и применения оригинальных творческих решений. Вместе с тем воплощение определённого визуального конструкта может быть продолжено и на постпродакшене. При этом требуется оправданный подход в применении нестандартных композиций, с избыточностью которых не следует злоупотреблять, так как благодаря незначительному количеству в визуальном про- изведении, они привлекают внимание зрителя и помогают заложить в изобразительный строй кадра более глубокий смысл.

Теоретическое осмысление трансформаций экранного пространства, безусловно, не абсолютно конечно. Потенциал комбинаторики композиции нуждается в дальнейшем уточнении и расширении, описании новых методов управления структурой кадра. В свете постоянного совершенствования современных подходов к созданию экранных композиций, как и технической базы, с помощью которой воспроизводится копия окружающей реципиента действительности, феномен «нестандартной» композиции в актуальных построениях экранного пространства как в сфере телевидения и кинематографа, так и визуальных искусств в целом требует дальнейшего изучения.

\section{БИБЛИОГРАФИЯ}

1. Дыко Л.П. Основы композиции в фотографии [Электронный ресурс]. - Режим доступа: http://www. photoline.ru/books/diko-osnovikompozicii.pdf (дата обращения: 25.11.2020).

2. Дыко Л.П., Головня А.Д. Фотокомпозиция. - М.: Искусство, 1962. - 261 с.

3. Композиция кадра и правило третей // 2016. дек., 6. [Электронный ресурс]. - Режим доступа: https:// bekarstudio.ru/kak-horosho-fotografirovat-ili-snimatvideo/article_post/kompozitsiya-kadra-i-pravilo-tretey (дата обращения: 26.09.2020).
4. Кулешов Л.В. Искусство кино. - Л.: Театр-Кино-Печать, 1929. - 155 с.

5. Малларме С. Сочинения в стихах и прозе: Сборник / Сост. Р. Дубровкин. На франц. яз. с параллельным рус. текстом. - М.: Радуга, 1995. - 568 с.

6. Маньковская Н.Б. Лебедь, закованный льдом. Эстетические воззрения Стефана Малларме // Художественная культура. - 2020. - № 1. - С. 1-28.

7. Свешников А.В. Актуальные проблемы композиции художественного изображения // Вестник ВГИК. 2019. - T. 11. - № 2. - С. 87-99. 